\title{
Synchronous Occurrence of Colloid Cyst With Intracranial Ossifying Fibromyxoid Tumor Masquerading as Meningioma
}

\author{
Sanjay Dhawan ${ }^{1}$, Tusharindra Lal ${ }^{2}$, P.N. Pandey ${ }^{3}$, Ravindra Saran ${ }^{4}$, Anutosh Singh ${ }^{3}$ \\ 1. Surgery, University of Minnesota, Minneapolis, USA 2. Surgery, Sri Ramachandra Institute of Higher Education and \\ Research, Chennai, IND 3. Neurosurgery, Maulana Azad Medical College/Lok Nayak Hospital, New Delhi, IND 4. \\ Neuro-Pathology, Gobind Ballabh Pant Institute of Postgraduate Medical Education and Research/Maulana Azad \\ Medical College, New Delhi, IND
}

Corresponding author: Sanjay Dhawan, sdhawan@umn.edu

\begin{abstract}
Ossifying fibromyxoid tumor (OFMT) is a rare fibro-osseous neoplasm. We present a case highlighting the occurrence of an intracranial OFMT masquerading as meningioma on imaging in a 46-year-old gentleman. Brain imaging revealed an extra-axial calcified lesion along the left cerebellar convexity appearing hypointense on T1- and T2-weighted MRI sequences with no post-contrast enhancement, suggestive of a meningioma. An intraventricular colloid cyst was also noted. The lesion, which was presumed to be meningioma, and the colloid cyst were resected in two subsequent operative settings. Histopathological examination of the calcified lesion confirmed the findings of an OFMT. This report aims to inform the physician about intracranial OFMT mimicking meningioma on imaging. In addition, since multiple brain tumors are not very common, the surgeon should always have a suspicion should there be any heterogeneous and peculiar radiological and histopathological characteristics.
\end{abstract}

Received 07/25/2020

Review began $07 / 30 / 2020$ Review ended 09/24/2020 Published 09/26/2020

๑) Copyright 2020 Dhawan et al. This is an open access article distributed under the terms of the Creative Commons Attribution License CC-BY 4.0., which permits unrestricted use, distribution, and reproduction in any medium, provided the original author and source are credited.
Categories: Medical Education, Neurology, Neurosurgery

Keywords: intracranial, ossifying fibromyxoid, meningioma, neurosurgery, radiology, brain tumor

\section{Introduction}

Ossifying fibromyxoid tumor (OFMT) was first described by Enzinger et al. in 1989 [1]. It is a rare fibroosseous neoplasm displaying an uncertain histogenesis and an uncertain line of differentiation [1].

OFMTs are most commonly found in the subcutaneous tissues of extremities or trunk [2]. The head and neck is an uncommon anatomical location for OFMT. To the best of our knowledge, intracranial OFMTs not originating from the base of the skull or sinuses have not been previously reported in the literature. We describe a case of intracranial OFMT located in the left cerebellar convexity that closely mimicked a meningioma on imaging in an immunocompetent male who presented with an extra-axial calcified lesion. The patient was also found to have an intraventricular colloid cyst. It is also worthwhile to note that the evidence of simultaneously occurring primary brain tumors in patients who do not have genetic disorders, such as neurofibromatosis or tuberous sclerosis, or have no prior history of cranial radiotherapy remain poorly established in the literature. Although a handful of cases reporting the simultaneous occurrence of intraventricular lesions with gliomas have been published in the literature, this study is perhaps the first of its kind to also report a synchronous occurrence of an intracranial OFMT with an intraventricular colloid cyst.

The PubMed database was thoroughly reviewed for articles reporting intracranial OFMT on June 22, 2020. The keywords used in our search were "intracranial ossifying fibroma" and "intracranial fibromyxoid tumor" [All Fields].

\section{Case Presentation}

A 46-year-old gentleman presented to the neurosurgery outpatient clinic with complaints of headache and vomiting of one-year duration. There was no family history of any age-related sporadic or familial neoplastic illness. A thorough neurological and physical examination was performed, and no evidence of neurocutaneous disorders such as café au lait spots, Lisch nodule, or adenoma sebaceum was found. No intraocular lesions were noted. The patient was fully oriented with no neurological deficit.

Magnetic resonance imaging (MRI) of the brain revealed an extra-axial calcified lesion along the left cerebellar convexity appearing hypointense on T1-weighted (TIW) and T2-weighted (T2W) sequences, with no post-contrast enhancement and showing blooming on SWI (susceptibility-weighted imaging), suggestive of a meningioma (Figure 1). The scan also described another well-defined lesion near the foramen of Monro, appearing isointense to hyperintense on $\mathrm{T} 1 \mathrm{~W}$, isointense to hypointense on $\mathrm{T} 2 \mathrm{~W}$ with no post-contrast enhancement with signal suppression on FLAIR (fluid-attenuated inversion recovery) and restricted 


\section{Cureus}

diffusion within the lesion, compatible with a colloid cyst (Figure 1). MRI was the only pre-operative imaging performed.
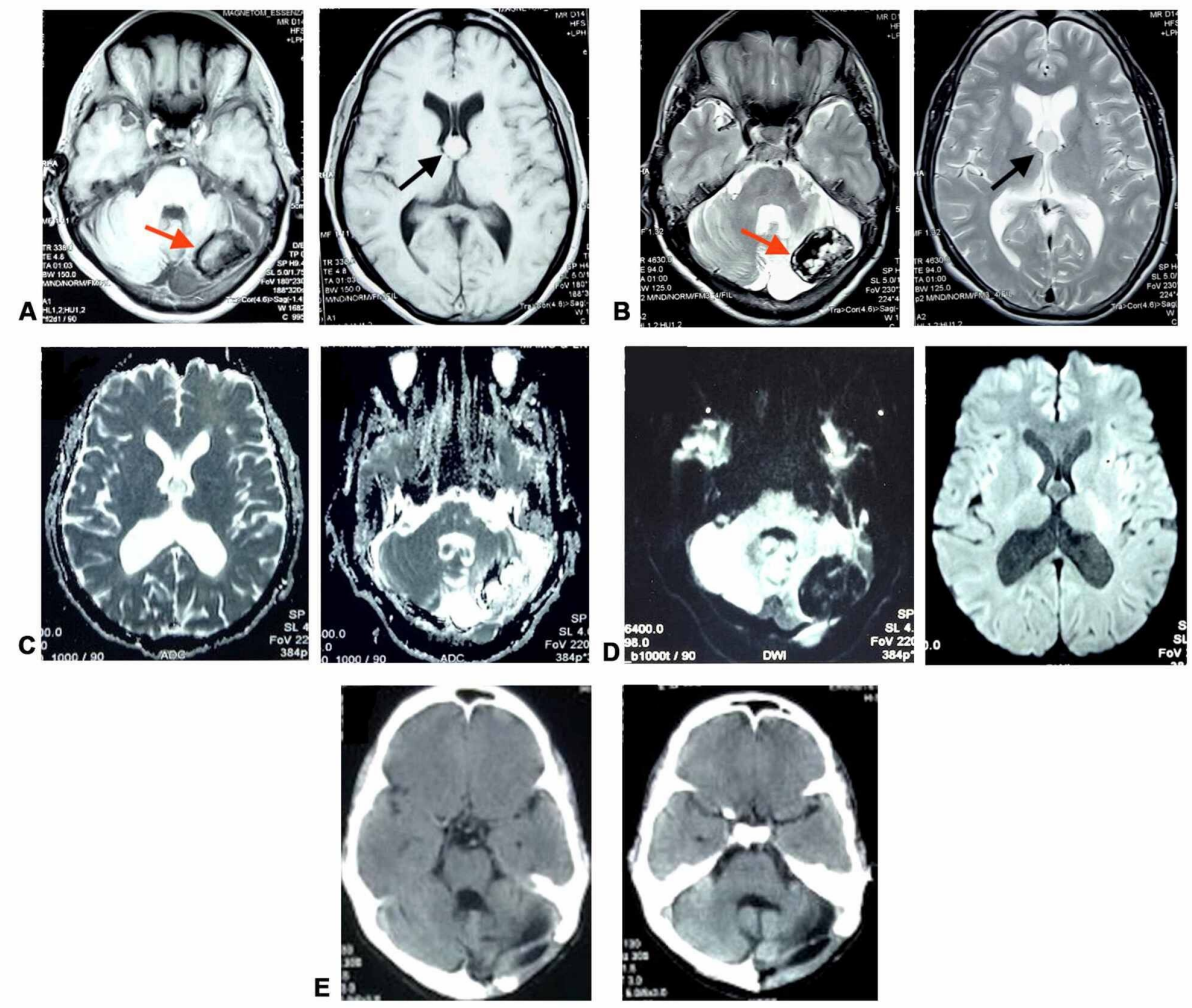

FIGURE 1: Well-defined extra-axial heterogeneous non-enhancing lesion seen in left cerebellar convexity with peripheral T1 and T2 hypointense rim and internal components showing mixed $\mathrm{T} 2$ hypo- and hyperintensity (red arrow). Left cerebellar atrophy is also seen. Another well-defined mildly $\mathrm{T} 1$ hyperintense and $\mathrm{T} 2$ isointense lesion is seen at the foramen of Monro, suggestive of colloid cyst (black arrow) (Figures $A$ and $B$ ). Figures $C$ and $D$ demonstrate the $D W I$ and the $A D C$ sequences. (E) Post-operative CT scan following left sub-occipital craniectomy, showing complete excision of fibromyxoid cerebellar lesion. The hyperdense colloid cyst lesion can be seen.

DWI, diffusion-weighted images; ADC, apparent diffusion coefficient; CT, computed tomography

\section{Operation and post-operative course}

The left cerebellar posterior fossa lesion was excised through a left sub-occipital craniectomy approach. Macroscopically, the tumor was tan, hard with a broad-based attachment. The post-operative course was uneventful. Post-operative cranial computed tomography (CT) revealed complete excision with a thin extraaxial bleed $(\sim 6 \mathrm{~mm}$ ), with a colloid cyst in the third ventricle (Figure 1). On histopathological examination (HPE), the hematoxylin and eosin section revealed thickened dura mater with adjacent reactive gliosis and foci of dystrophic calcification and the periodic acid-Schiff-diastase (PAS-diastase)/Alcian blue staining demonstrated intervening pools of mucin, suggestive of an OFMT (Figure 2). 


\section{Cureus}
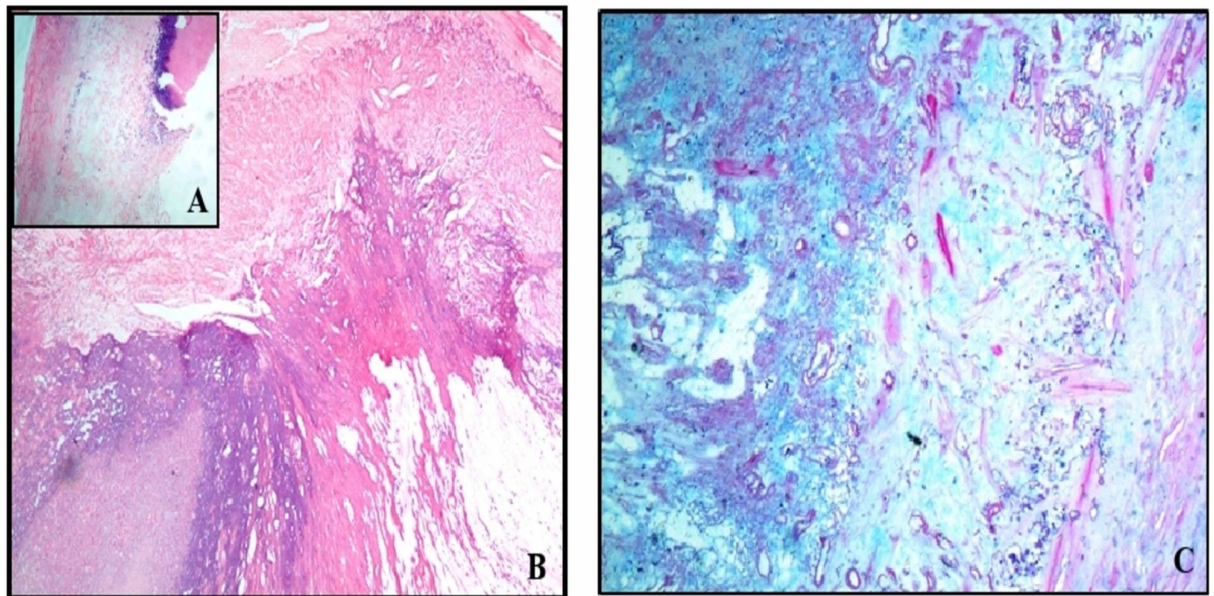

FIGURE 2: A section stained using hematoxylin and eosin reveals thickened dura mater with adjacent reactive gliosis and foci of dystrophic calcification, 10x (A), 20x (B). Periodic acid-Schiffdiastase/Alcian blue staining (20x) shows intervening pools of mucin (C).

The patient was readmitted after eight weeks for the excision of the colloid cyst, which was performed through a right frontoparietal craniotomy through an anterior transcallosal approach. Grossly, the lesion was whitish, dome-shaped, partially obliterating the foramen of Monro, containing viscous fluid. Simple columnar epithelium lining fibrous wall with low cellularity on histopathology confirmed the lesion as a colloid cyst. The post-operative course was uneventful.

The patient has been following with us for the last two years and is doing fine, with no post-operative neurological deficit.

\section{Discussion}

Enzinger et al. in a study on 59 cases described OFMT for the first time as a rare deep soft tissue tumor of uncertain differentiation predominantly occurring in the adult male population (male-to-female ratio of $1.5: 1$ ). Majority of the cases involved the lower extremities [1]. Relevant clinical studies that were available in English language are described in Table 1 [3-17].

\begin{tabular}{|c|c|c|c|c|}
\hline $\begin{array}{l}\text { Author, } \\
\text { year }\end{array}$ & Country & Area involved & Imaging & Histopathology \\
\hline $\begin{array}{l}\text { Scott et } \\
\text { al., } \\
1971[3]\end{array}$ & USA & $\begin{array}{l}\text { Orbits, paranasal } \\
\text { sinuses, right } \\
\text { maxillary antrum with } \\
\text { intracranial extension }\end{array}$ & $\begin{array}{l}\text { Ossifying fibroma involving the mid-anterior fossa } \\
\text { bilaterally, and extending posteriorly to the clinoid } \\
\text { processes }\end{array}$ & - \\
\hline $\begin{array}{l}\text { Tomita et } \\
\text { al., } \\
1981[4]\end{array}$ & USA & $\begin{array}{l}\text { Maxillary sinus with } \\
\text { intracranial extension }\end{array}$ & $\begin{array}{l}\text { CT: involvement of nasal cavity with base of the skull and } \\
\text { cribriform plate }\end{array}$ & $\begin{array}{l}\text { Highly cellular } \\
\text { fibroblastic } \\
\text { proliferation with foci of } \\
\text { ossification and } \\
\text { calcification. } \\
\text { Herringbone pattern } \\
\text { arrangement of } \\
\text { fibroblastic spindle cell } \\
\text { proliferation }\end{array}$ \\
\hline $\begin{array}{l}\text { Ito et al., } \\
1984[5]\end{array}$ & Japan & $\begin{array}{l}\text { Right frontoethmoid } \\
\text { sinus }\end{array}$ & $\begin{array}{l}\text { CT: dense bony tumor with sharp demarcation, eggshell } \\
\text { appearance extending into the right frontoethmoid sinus, } \\
\text { the right orbit, and intracranial cavity }\end{array}$ & $\begin{array}{l}\text { Small calcified spicules } \\
\text { interspersed freely in } \\
\text { dense fibrous stroma } \\
\text { without mitosis. No } \\
\text { psammoma bodies. }\end{array}$ \\
\hline Blitzer et & & br & & \\
\hline
\end{tabular}




\section{Cureus}

\begin{tabular}{|c|c|c|c|c|}
\hline $\begin{array}{l}\text { al., } \\
1989[6]\end{array}$ & USA & $\begin{array}{l}\text { of the frontal and } \\
\text { ethmoidal sinuses }\end{array}$ & CT: ossified lesion of the paranasal sinuses & - \\
\hline $\begin{array}{l}\text { Wenig et } \\
\text { al., } \\
1995[7]\end{array}$ & USA & Sinonasal tract & $\begin{array}{l}\text { Osseous, soft tissue mass, } \pm \text { bone erosion and intracranial } \\
\text { extension (anterior cranial fossa) }\end{array}$ & $\begin{array}{l}\text { Psammomatoid bodies } \\
\text { admixed with } \\
\text { myxomatous material } \\
\text { and scattered giant } \\
\text { cells }\end{array}$ \\
\hline $\begin{array}{l}\text { Ruggieri } \\
\text { et al., } \\
1996 \text { [8] }\end{array}$ & Italy & $\begin{array}{l}\text { Frontoparietotemporal } \\
\text { ossifying fibroma with } \\
\text { intracranial growth }\end{array}$ & $\begin{array}{l}\text { CT: thickening of both the right sphenoidal wing and the } \\
\text { right temporal table T1W MRI: parietal bone lesion } \\
\text { displacing the frontoparietal brain lobes }\end{array}$ & $\begin{array}{l}\text { Lamellar bone with } \\
\text { cellular fibrous stroma }\end{array}$ \\
\hline $\begin{array}{l}\text { Noudel et } \\
\text { al., } \\
2009[9]\end{array}$ & France & $\begin{array}{l}\text { Right paranasal } \\
\text { sinuses }\end{array}$ & $\begin{array}{l}\text { CT: sinonasal mass protruding into the right globe } \\
\text { laterally. T1W MRI: well-circumscribed soft tissue mass } \\
\text { with homogenous enhancement filling the right nasal } \\
\text { cavity, ethmoid sinus with slight extension through the } \\
\text { anterior cranial fossa }\end{array}$ & $\begin{array}{l}\text { Densely fibrous stroma } \\
\text { composed of fusiform } \\
\text { cells with storiform } \\
\text { appearance with round } \\
\text { basophilic } \\
\text { calcifications }\end{array}$ \\
\hline $\begin{array}{l}\text { Kansal et } \\
\text { al., } \\
2010[10]\end{array}$ & India & $\begin{array}{l}\text { Petromastoid bone } \\
\text { with intracranial } \\
\text { extension }\end{array}$ & $\begin{array}{l}\text { CT: expansile lesion of the right petromastoid bone MRI: } \\
\text { contrast-enhancing mass involving the right petromastoid } \\
\text { bone with extradural extension compressing the cerebellar } \\
\text { hemisphere }\end{array}$ & $\begin{array}{l}\text { Fibroblastic } \\
\text { proliferation with } \\
\text { cementum and bony } \\
\text { trabeculae }\end{array}$ \\
\hline $\begin{array}{l}\text { Sarode et } \\
\text { al., } \\
2011[11]\end{array}$ & India & Left mandible & $\begin{array}{l}\text { CT: multilocular expansile lesion of the left mandible with } \\
\text { heterogeneous attenuation }\end{array}$ & $\begin{array}{l}\text { Densely cellular fibrous } \\
\text { stroma interspersed } \\
\text { with psammoma } \\
\text { bodies }\end{array}$ \\
\hline $\begin{array}{l}\text { Rowland } \\
\text { et al., } \\
2013 \text { [12] }\end{array}$ & USA & Skull base & $\begin{array}{l}\text { CT: sphenoidal bone ossifying fibroma filling the } \\
\text { sphenoidal sinus and extending intracranially. Left } \\
\text { abducens nerve involvement on MRI }\end{array}$ & $\begin{array}{l}\text { Cystic transformation } \\
\text { with active processes }\end{array}$ \\
\hline $\begin{array}{l}\text { Lee et al., } \\
2014 \text { [13] }\end{array}$ & $\begin{array}{l}\text { Republic } \\
\text { of Korea }\end{array}$ & Temporal bone & $\begin{array}{l}\text { CT case I: } 2.9 \mathrm{~cm} \text { calcified mass in the temporal bone; } \\
\text { case II: } 5.5 \mathrm{~cm} \text { enhancing mass with internal cartilaginous } \\
\text { matrix in the temporal bone }\end{array}$ & $\begin{array}{l}\text { Osseous islands } \\
\text { scattered throughout } \\
\text { the bland fibrous } \\
\text { stroma }\end{array}$ \\
\hline $\begin{array}{l}\text { Al- } \\
\text { Sharhan } \\
\text { et al., } \\
2016 \text { [14] }\end{array}$ & $\begin{array}{l}\text { Saudi } \\
\text { Arabia }\end{array}$ & Ethmoid sinus & $\begin{array}{l}\text { CT: well-defined expansile lesion of the mid-ethmoid and } \\
\text { frontal sinus with extensive bone remodelling and thinning } \\
\text { of the adjacent lamina papyracea and superior orbital roof, } \\
\text { with internal heterogeneous soft tissue component. MRI: } \\
\text { concentric soft tissue and multiple fluid levels of high } \\
\text { signal intensity on T1 and T2 sequences with mild } \\
\text { enhancement post-contrast administration }\end{array}$ & $\begin{array}{l}\text { Numerous small } \\
\text { ossicles or } \\
\text { psammomatoid bodies } \\
\text { embedded in the } \\
\text { cellular fibrous stroma } \\
\text { with cysts lined by } \\
\text { fibroblasts and } \\
\text { histiocytes }\end{array}$ \\
\hline $\begin{array}{l}\text { Ghosal et } \\
\text { al., } \\
2016[15]\end{array}$ & India & $\begin{array}{l}\text { Left maxillo-ethmoid } \\
\text { sinus lesion }\end{array}$ & $\begin{array}{l}\text { CT: calcifications within the lesion; T1W MRI: lobulated } \\
\text { enhancing mass lesion in left frontal and ethmoid sinuses } \\
\text { with intracranial extension into the crista galli and anterior } \\
\text { interhemispheric fissure }\end{array}$ & $\begin{array}{l}\text { Oval to spindle cells } \\
\text { dispersed in a myxoid } \\
\text { extracellular matrix and } \\
\text { arranged in focal } \\
\text { lobulated architecture }\end{array}$ \\
\hline $\begin{array}{l}\text { Jiang et } \\
\text { al., } \\
2018[16]\end{array}$ & USA & $\begin{array}{l}\text { Squamous suture of } \\
\text { the temporal bone }\end{array}$ & CT: Bullough's bump of the left temporal bone & $\begin{array}{l}\text { Oval osseous islands } \\
\text { dispersed throughout a } \\
\text { bland fibrous stroma. } \\
\text { The pathological } \\
\text { diagnosis was } \\
\text { "Bullough's bump", a } \\
\text { rare, benign fibro- } \\
\text { osseous neoplasm }\end{array}$ \\
\hline $\begin{array}{l}\text { Mukherjee } \\
\text { et al., } \\
2019 \text { [17] }\end{array}$ & India & Orbit & $\begin{array}{l}\text { CT: lobulated expansile fibro-osseous lesion involving the } \\
\text { greater wing of the sphenoid and orbital roof without } \\
\text { intracranial extension }\end{array}$ & $\begin{array}{l}\text { Fibroblast rich stroma } \\
\text { with bony trabeculae; } \\
\text { osteoblastic rimming } \\
\text { without any mitotic } \\
\text { activity }\end{array}$ \\
\hline
\end{tabular}


The brain imaging in our case revealed an extra-axial calcified lesion along the left cerebellar convexity with features suggestive of a calcified meningioma. HPE revealed thickened dura mater and fibro-collagenous tissue showing foci of dystrophic calcification with low cellularity and mitotic rate $<2 / 50$ high powered fields (HPF), suggestive of a "typical OFMT". The HPE findings were consistent with the Folpe and Weiss classification of OFMT, which described "typical OFMT" as those showing low nuclear grade and low cellularity and mitotic rate $<2 / 50 \mathrm{HPF}$ [2]. In contrast, malignant OFMT shows a high nuclear grade or high cellularity and mitotic activity $>2 / 50 \mathrm{HPF}[2]$.

OFMT is a much rarer entity as compared to meningiomas, which account for $14 \%-19 \%$ of the primary intracranial neoplasms [18]. We would like to highlight that an OFMT lesion on imaging could masquerade as a calcified meningioma, like in this case.

Although most malignant OFMT may be recognized histologically, a small number of otherwise typical OFMT may behave in a clinically malignant fashion, supporting their reclassification as tumors of intermediate malignancy [2]. Recognition of malignant OFMT should assist in the clinical management of patients with this rare soft tissue neoplasm.

Immunohistochemistry analysis of the ossifying fibromyxoid lesion revealed positivity for S-100 (polyclonal, 1:800, Dako, Glostrup, Denmark), suggesting Schwannian differentiation. This conforms to the concept of neuronal differentiation of OFMT as laid by Folpe and Weiss [2]. Immunohistochemical staining for markers such as NSE and CD57 would be helpful in the meningioma diagnosis of such lesions, which can help us differentiate these lesions better from OFMTs.

To the best of our knowledge, this case is also the first documentation depicting the synchronous occurrence of an OFMT with an intraventricular colloid cyst. Different hypotheses exist, which explain the coexistence of multiple primary intracranial tumors of different histogenesis in different compartments of the brain in patients without neurocutaneous disorders or cranial radiotherapy. Gelabert et al. reported the simultaneous occurrence of a frontal lobe astrocytoma and a colloid cyst of the third ventricle, both derived from displaced primitive neuroectodermal cells, suggesting the role of a single oncogenic factor in producing different tumors in the same individual [19]. Another hypothesis suggested by Karami et al. explains that this phenomenon of simultaneous occurrence of histologically different tumors in different or same areas of the brain could be purely coincidental [20].

There is no defined treatment strategy regarding which lesion should be treated first in patients with simultaneous brain tumors. We operated the OFMT first followed by the excision of the colloid cyst. It can be said that it is the surgeon's preference in corroboration with the patient profile as to which lesion should be dealt with first.

\section{Conclusions}

OFMTs are believed to commonly arise from the skull base locations or paranasal sinuses. This case reports the presence intracranial OFMT arising from the left cerebellar convexity. We believe this case would help in informing the physicians regarding the management of extra-axial calcified lesions where an OFMT could masquerade as a calcified meningioma, as reported in this case. This is also the first case to report synchronous occurrence of intracranial fibromyxoid tumor with a colloid cyst. Since synchronous brain tumors are not very common, the surgeon should always have a suspicion should there be any heterogeneous and peculiar radiological and histopathological characteristics.

\section{Additional Information}

\section{Disclosures}

Human subjects: Consent was obtained by all participants in this study. Conflicts of interest: In compliance with the ICMJE uniform disclosure form, all authors declare the following: Payment/services info: All authors have declared that no financial support was received from any organization for the submitted work. Financial relationships: All authors have declared that they have no financial relationships at present or within the previous three years with any organizations that might have an interest in the submitted work. Other relationships: All authors have declared that there are no other relationships or activities that could appear to have influenced the submitted work.

\section{Acknowledgements}

Thanks to Drs. Ritu Srivastava, Rahul Tiwari, Sheikh Ozair Nizar, Puneet Gulati, and Shrikant Sharma for their contribution. 


\section{References}

1. Enzinger FM, Weiss SW, Liang CY: Ossifying fibromyxoid tumor of soft parts: a clinicopathological analysis of 59 cases. Am J Surg Pathol. 1989, 13:817-827. 10.1097/00000478-198910000-00001

2. Folpe AL, Weiss SW: Ossifying fibromyxoid tumor of soft parts: a clinicopathologic study of 70 cases with emphasis on atypical and malignant variants. Am J Surg Pathol. 2003, 27:421-431. 10.1097/00000478200304000-00001

3. Scott M, Peale AR, Croissant PD: Intracranial midline anterior fossae ossifying fibroma invading orbits, paranasal sinuses, and right maxillary antrum. Case report. J Neurosurg. 1971, 34:827-831. 10.3171/jns.1971.34.6.0827

4. Tomita T, Huvos AG, Shah J, Sundaresan N: Giant ossifying fibroma of the nasal cavity with intracranial extension. Acta Neurochir (Wien). 1981, 56:65-71. 10.1007/BF01400973

5. Ito H, Hasegawa T, Hwang WZ, Yamamoto S: Ossifying fibroma of the frontoethmoid sinus . Surg Neurol. 1984, 22:397-402. 10.1016/0090-3019(84)90146-0

6. Blitzer A, Post KD, Conley J: Craniofacial resection of ossifying fibromas and osteomas of the sinuses . Arch Otolaryngol Head Neck Surg. 1989, 115:1112-1115. 10.1001/archotol.1989.01860330102027

7. Wenig BM, Vinh TN, Smirniotopoulos JG, Fowler CB, Houston GD, Heffner DK: Aggressive psammomatoid ossifying fibromas of the sinonasal region: a clinicopathologic study of a distinct group of fibro-osseous lesions. Cancer. 1995, 76:31155-1165. 10.1002/1097-0142(19951001)76:7<1155::aidcncr2820760710>3.0.co;2-p

8. Ruggieri M, Pavone V, Tiné A, et al.: Ossifying fibroma of the skull in a patient with neurofibromatosis type 1. Case report. J Neurosurg. 1996, 85:941-944. 10.3171/jns.1996.85.5.0941

9. Noudel R, Chauvet E, Cahn V, Mérol JC, Chays A, Rousseaux P: Transcranial resection of a large sinonasal juvenile psammomatoid ossifying fibroma. Childs Nerv Syst. 2009, 25:1115-1120. 10.1007/s00381-009-0867$\mathrm{x}$

10. Kansal R, Sharma A, Gaikwad N, Mahore A, Goel A: Cemento-ossifying fibroma presenting as a posterior fossa mass lesion. Turk Neurosurg. 2010, 20:265-268. 10.5137/1019-5149.JTN.2327-09.0

11. Sarode SC, Sarode GS, Waknis P, Patil A, Jashika M: Juvenile psammomatoid ossifying fibroma: a review . Oral Oncol. 2011, 47:1110-1116. 10.1016/j.oraloncology.2011.06.513

12. Rowland NC, Jermakowicz WJ, Tihan T, El-Sayed IH, McDermott MW: Subacute cystic expansion of intracranial juvenile psammomatoid ossifying fibroma. J Neurosurg Pediatr. 2013, 11:687-691. 10.3171/2013.2.PEDS12253

13. Lee M, Song JS, Chun SM, Lee JH, Hong SH, Cho KJ: Protuberant fibro-osseous lesions of the temporal bone: two additional case reports. Am J Surg Pathol. 2014, 38:1510-1515. 10.1097/PAS.0000000000000302

14. Al-Sharhan SS, Ashoor MM, Al-Nemer AM: Psammomatoid ossifying fibroma of the ethmoid sinus with secondary intracranial aneurymal bone cyst: a case report and literature review. Saudi J Med Med Sci. 2016, 4:125-128. 10.4103/1658-631X.178350

15. Ghosal N, Rudrappa S, Tandon AS, Rao P, Gopal S: Atypical ossifying fibromyxoid tumor in left maxilloethmoid sinus with intracranial extension in a child. Clin Neuropathol. 2016, 35:329-332. 10.5414/NP300908

16. Jiang B, Mushlin H, Zhang L, James AW, Cohen AR: Bullough's bump: unusual protuberant fibro-osseous tumor of the temporal bone. Case report. J Neurosurg Pediatr. 2018, 21:107-111. 10.3171/2017.8.PEDS17391

17. Mukherjee B, Devi U, Agarkar S: Recurrent benign ossifying fibroma of the orbit - clinical, radiological profile and management options in a child [published correction appears in. Orbit. 2019, 38:252-255. 10.1080/01676830.2018.1505919

18. Rampurwala M, Pazooki M, Schauer P: Delayed hepatic metastasis from a benign fibroblastic meningioma thirty-one years after surgical resection of the intracranial tumor. J Clin Oncol. 2011, 29:214-215. 10.1200/JCO.2010.32.6694

19. Gelabert M, Bollar A, Martinez R, Allut AG: Coincidence of a frontal lobe astrocytoma and colloid cyst of the third ventricle. Neurochirurgia (Stuttg). 1991, 34:69-70. 10.1055/s-2008-1052058

20. Karami KJ, Poulik J, Rabah R, Krass J, Sood S: Simultaneous choroid plexus carcinoma and pilocytic astrocytoma in a pediatric patient. J Neurosurg Pediatr. 2010, 5:104-112. 10.3171/2009.8.PEDS09117 